\title{
REACTIVE POWER COMPENSATION BASED OPTIMISATION OF MICRO-SCALE STAND-ALONE PHOTOVOLTAIC SYSTEMS
}

\author{
Altan KALAY, Muğla Sıtkı Koçman University, Yatağan Vocational School, Muğla, TURKEY altankalay@mu.edu.tr \\ (iDhttps://orcid.org/0000-0002-4930-7172) \\ Koray ÜLGEN*, Ege University, Solar Energy Institute, Bornova, İzmir, TURKEY, koray.ulgen@ege.edu.tr \\ (iDhttps://orcid.org/0000-0002-9560-1727) \\ Ali AĞÇAL, Süleyman Demirel University, Engineering Faculty, Electric-Electronic Engineering, Isparta, TURKEY \\ aliagcal@sdu.edu.tr \\ (iD https://orcid.org/0000-0003-0965-4038) \\ Received: 11.11.2020, Accepted: 27.02.2021 \\ Research Article \\ DOI: $10.22531 /$ muglajsci.824451
}

*Corresponding author

\begin{abstract}
Inductive loads demand reactive power that does not turn into useful energy from the energy source, adversely affects system components, and releases excessive thermal energy. The control of the power factor (cos $\varphi$ ) decreases the negative effect of reactive power in the system by performing reactive power compensation (RPC). In this study, RPC is applied to a Photovoltaic (PV) system to increase the overall system. The designed system's main components' mathematical modeling and performance simulations are made using MATLAB codes and Simulink modellings. Simulation-based performance data were compared with the data obtained from the experimental setup. As a result of the study, the system's currentcarrying capacity (CCC) is increased, a reduction in thermal energy is obtained; therefore, the system performance is optimized.
\end{abstract}

Keywords: Reactive Power Compensation (RPC), current-carrying capacity (CCC), system efficiency, performance optimization, PV System

\section{KÜÇÜK ÖLÇEKLİ ADA TIPII PV (FOTOVOLTAİK) SISTEMLERINIIN REAKTİF GÜÇ KOMPANZASYONU TABANLI OPTIMIZASYONU}

Özet

Endüktif karakterli olan yükler; enerji kaynağından hiçbir şekilde işe dönüşmeyen, sistem donanımları üzerinde olumsuz sonuçlar doğuran ve fazladan termal enerji açı̆̆a çıkaran reaktif güç talebinde bulunurlar. Reaktif gücün sistemde yarattığı olumsuz etki, reaktif güç kompanzasyonu ile güç katsayısı kontrolü gerçekleştirilerek minimumda tutulur. Bu çalışmada, bir PV sisteme reaktif güç kompanzasyonu kontrolü yapllarak sistemde genel olarak performans optimizasyonu gerçekleștirilmiștir. Çalıșma kapsamında, dizayn edilen sistemin ana bileșenlerinin matematiksel modellemeleri gerçekleştirilerek MATLAB kodları, Simulink modellemeleri marifetiyle performans simülasyonları yapılmıştır. Deneysel uygulamadan elde edilen veriler ile simülasyon esaslı performans verileri karşılaştırılmıştır. Çalışma sonucunda, sistemin akım taşıma kapasitesi artırılmış, termal enerjide bir azalma elde edilmiş, dolayısıla sistem performansının optimizasyonu sağlanmıștır.

Anahtar Kelimeler: Reaktif Güç Kompanzasyonu, akım taşıma kapasitesi, sistem verimi, performans optimizasyonu, PV sistem.

Cite

KALAY A., ÜLGEN K., AĞÇAL A. (2021). "Reactıve Power Compensatıon Based Optımısatıon of Mıcro-Scale Stand-Alone Photovoltaic Systems", Mugla Journal of Science and Technology, 7(1), 25-35.

\section{Introduction}

The efficiency in commercial PV systems that place on energy markets is around $15-19 \%$ on a global scale.

Some efficiency factors determine the total efficiency of a PV system. These factors can divide into several groups such as the efficiency of the PV module, inverter, wiring, and battery, degradation of PV module, variation in solar radiation, module temperature, fill factor (FF), parasitic resistances, shading, soiling, and tilt angle [1]. Millions of dollars are spent, and many techniques have been developed to increase this efficiency. The methods proposed to improve efficiency are, e.g., solar tracking, maximum power point tracking (MPPT), PV panel cooling, fuzzy logic control (FLC), and Photovoltaicboosting converter power.

The first of these techniques, which consist of some subtechniques, is called solar tracking. Applied by way of 
tracking the sun via a controller, it increases the PV module's efficiency. One of these sub-techniques refers to one-axis 3-position sun-tracking and dual-axis position tracking. The one-axis 3-position sun-tracking system technique is very complicated and expensive due to heavy units and easily malfunctioning and complicated installation [2]. Dual-axis position tracking design has some inconveniences such as difficulties in installation, the complexity of mechanism and structure, overcostly, and the database storage media [3]. As a result, they do not have widespread usage.

The second technique is called MPPT. An MPPT is a converter that optimizes the match between the PV panels and the battery bank or utility grid. To put it simply, they convert to higher voltage DC output than solar panels.

Different control algorithms were applied on the converter floor at MPPT. One of the most necessary PV systems hardware developed to increase efficiency. There are many control algorithms in MPPT for the optimization of PV systems. For easing of application, the perturb \& observe (P\&O) method is one of the most preferred methods. However, in this method, the oscillation problem is inevitable. Some of the new approaches in MPPT algorithms are Using Neural Network MPPT' and 'Predictive Control of Converter.' [4] Efforts to increase efficiency and optimizing PV systems gained intensity in various parts of the system, significantly reducing the panel surface heat.

One technique developed to decrease the PV panel's thermal efficiency, the water spraying on the PV panel surface, can be another example of a scientific study on efficiency increase [5].

Besides, factors such as placing PV panels with maximum radiation gain, avoiding shading, paying attention to panel-inverter compatibility, and selecting inverter output AC cable cross-section are other efficiency-increasing factors [6].

Improved efficiency of fuzzy logic control (FLC) of PMBLDC for PV pumping system application is another example of a PV system optimization with motor control [7]. This control system becomes highly non-linear and analyzes how system stability is a complicated process. For such reasons, the flexibility in the FLC design is reduced [8].

Another study on the PV motor system's performance optimization is a dynamic performance of a photovoltaic-boost converter-powered DC motor-pump system [9]. DC motors were preferred more in PV systems due to low energy conversion and easy setup at first $[10,11]$. Nevertheless, on the other hand, some operational PV-DC pump system has shown that these schemes suffer from maintenance and sustainability problems. However, this solution is limited only to lowpower PV systems [12]. The induction motor-based PV systems offer an alternative for a more reliable and are sustainable off-grid system [13].

\section{Contributions}

Increasing transmission efficiency is one factor that affects the total efficiency of a PV system. It refers to a process during energy transmission between inverter output and load. The present study was performed to increase the PV system's efficiency, unlike the MPPT, sun tracking, and PV panel-cell-based studies. The system's total CCC was developed via RPC, an electrical method applied with the system and the load. Thus, general system performance is achieved finally.

\section{Methods}

Most of the loads are inductive loads requiring reactive power because of low-value power factors [14]. Inductive loads such as induction motors, capacitive loads such as UPS, consume reactive power and active power due to their energy source characters. The increase of reactive power consumption in the system will also cause the power factor ( $\cos$ ? ) to decrease. Power factor adjustment decreases the efficiency as it increases thermal losses if used in long-distance energy transmissions. Instead will be more efficient to RPC as close to the load possible [15]. Low power factor has some effects on transmission lines as listed below [16, 17, 18]:

1. The transformers at power stations and substations draw the magnetizing current

2. more power with low power factor flow through the systems.

3. The generated KVA and KW capacities will have a low power factor. The efficiency of the generator is decreased.

4. The transformers connected to transmission lines and distribution feeders will have the effect of the decrease in Kw capacity with the reduction in power factor and an increase in line voltage; thus, transformers are adversely affected.

5. Low power coefficient affects by switchgear and busbar: because the cross-sectional area of busbars and the contact bars account for the same amount of power to be delivered at low power factors.

\subsection{The System}

The system based on the operation is a PV System developed for water pumping-based usage in rural areas with no grid connection. In general, the system's essential components are as follows (Fig. 9).

- $\quad 1.8 \mathrm{kWp}$ PV array,

- solar inverter with 2,5 KVA soft starter feature,

- safety elements,

- 1,1 kW power 3-phase asynchronous motor (used as magnetic torque source),

- 1,1 kW power 3-phase asynchronous motor,

- compensation elements,

- voltage filtering transformer. 


\subsection{Mathematical Modelling and Equivalent Circuit for Design of PV System}

The scientific basis on which the study is constituted four main networks.

The first of these networks is the basic mathematical modelling of the PV System and the equivalent circuit creation. PV design's fundamental element creates an energy source for the working system. Simulink modelling was carried out in line with the PV module equivalent circuit parameters and equations. An equivalent circuit of the PV cell expressed as a photodiode with a sizeable p-n junction can define PV arrays and modules. Basic equations and electrical equivalent circuit of a non-linear PV module is about the following (Fig.1)

$I=I_{p h}-I_{d}-I_{r}$

$I_{p h}=I_{\text {sho }}\left(\frac{s}{1000}\right)+J_{0}\left(T-T_{\text {ref }}\right)$

$I_{d}=I_{0}\left[\exp \left\{\frac{q\left(V+R_{s} I\right)}{n K T}\right\}-1\right]$,

$I_{0}=I_{d 0}\left(\frac{T}{T_{r e f}}\right)^{3} \exp \left\{\frac{q E_{g}}{n k}\left(\frac{1}{T_{r e f}}-\frac{1}{T}\right)\right\}$

$I_{r}=\frac{V+R_{s} I}{R_{s h}}$
Figure 1. Equivalent circuit of a non-linear PN module.

Hence, $\mathrm{S}$ is the solar insolation in $\mathrm{W} / \mathrm{m}, T_{\text {ref }}$ the reference temperature $(298 \mathrm{~K}), \mathrm{T}$ is the cell temperature, $E_{g}$ is the bandgap energy of the cell semiconductor, $\mathrm{k}$ is Boltzmann constant, $R_{s}$ is the series resistance, $\mathrm{R}_{s h}$ is the shunt resistance, $\mathrm{n}$ is the diode emission factor. $I_{d 0}$ is the diode reverse current, $I_{s h 0}$ is the short-circuit current at reference state and $j_{0}$ is its temperature coefficient [19].

Based on these equations, Simulink modelling of PV cell was performed first and then added to PV string modelling (Fig. 2).

Designed PV system module data are given in Table 1.

Table 1. PV module data.

\begin{tabular}{rcccc}
\hline $\mathrm{V}_{O C}$ & $\mathrm{~V}_{M P P}$ & $\mathrm{I}_{S C}$ & $\mathrm{I}_{M P P}$ & $\mathrm{P}_{O U T}$ \\
\hline $85 \mathrm{~V}$ & $63 \mathrm{~V}$ & $1,12 \mathrm{~A}$ & $0,92 \mathrm{~A}$ & $58 \mathrm{~W}$ \\
\hline
\end{tabular}

As a result of the system design that feeds the load, the PV array comprises connected five parallel arms and eight series panels (Fig.3).
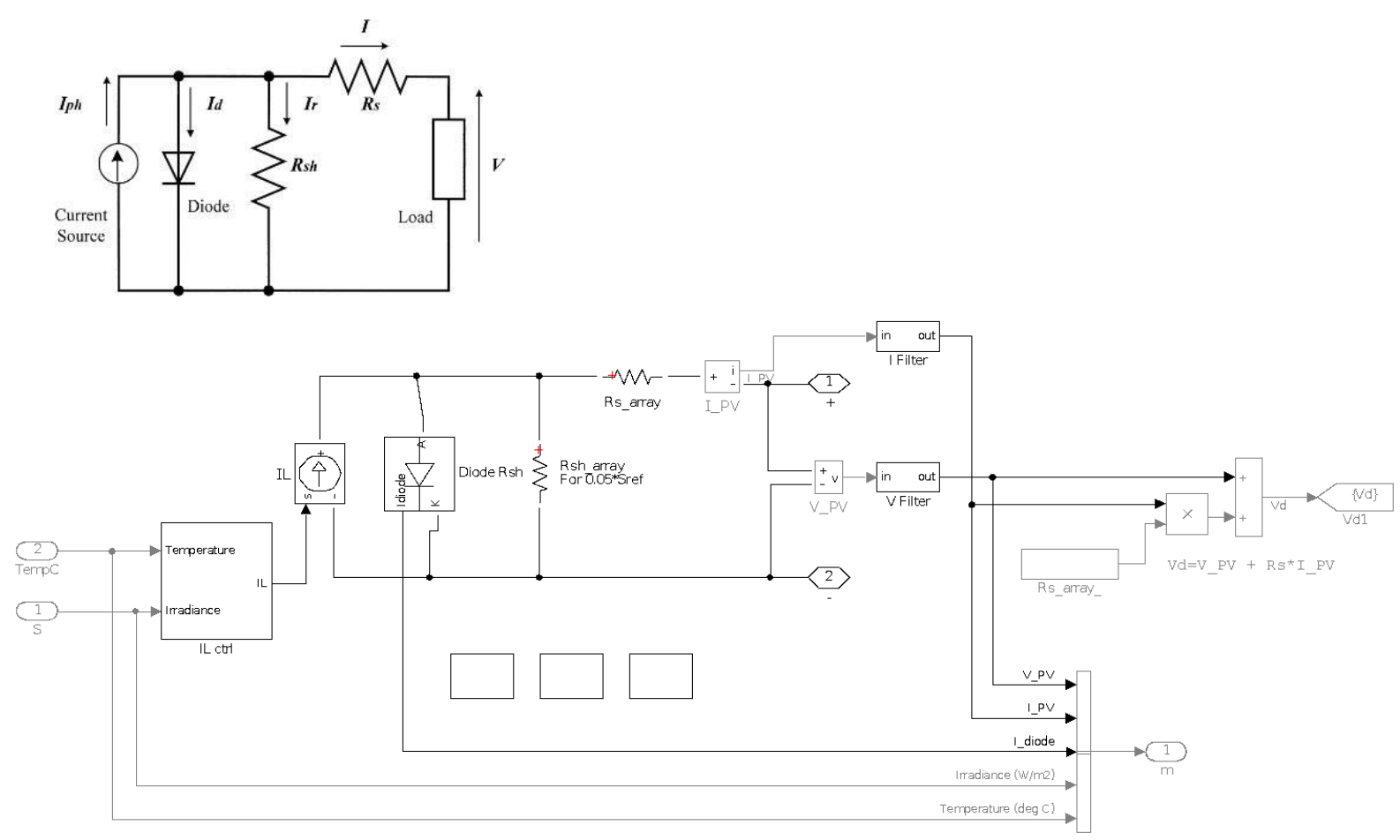

Figure 2. PV array Simulink modelling. 


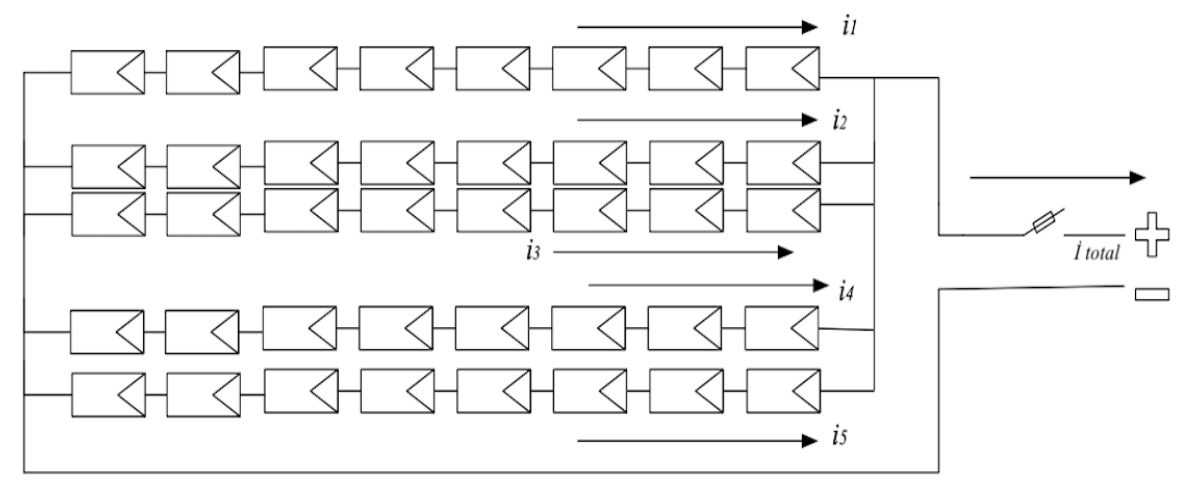

Figure 3. The topology of PV array.

\subsection{Modelling induction motor and equivalent}

\section{circuit}

Equivalent circuit of Three-phase induction motor to be supplied by the system created and the necessary calculations for the values of the circuit parameters have been taken by encoding to the MATLAB environment (Fig. 4). Three-phase induction motors (TIM) operating under steady-state regimes are commonly modelled using a per-phase equivalent circuit. This model consists of calculating quantities such as line current, power factor, input-output power, and efficiency only as a function of supply voltage, frequency, and slips [20].

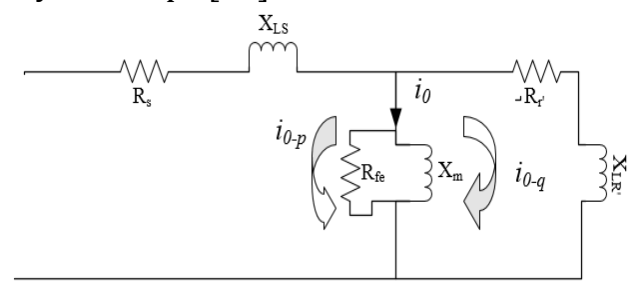

Figure 4. Induction motor per phase equivalent circuit.

\subsection{Reactive power compensation system design and modelling}

System parameter data is obtained through the necessary modelling and equations for RPC. Currentvoltage and power phasor diagrams before and after shunt RPC application in the system are as follows (Fig. $5,6,7)[21]$;

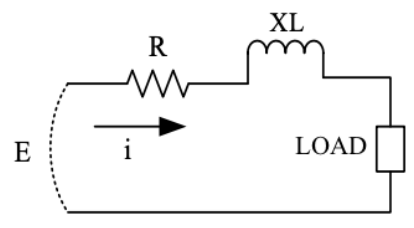

(a)

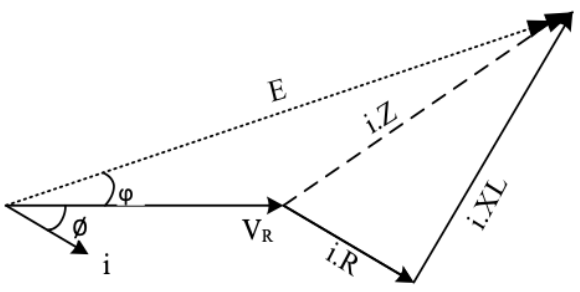

(b)

Figure 5. (a) Single-line diagram of an uncompensated transmission line, (b) An Uncompensated SingleTransmission line Phasor diagram.

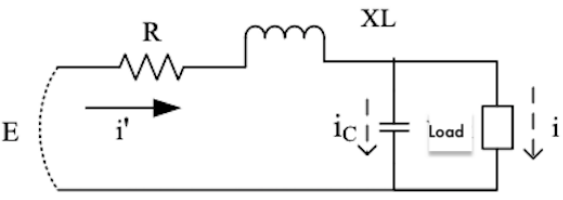

(a)

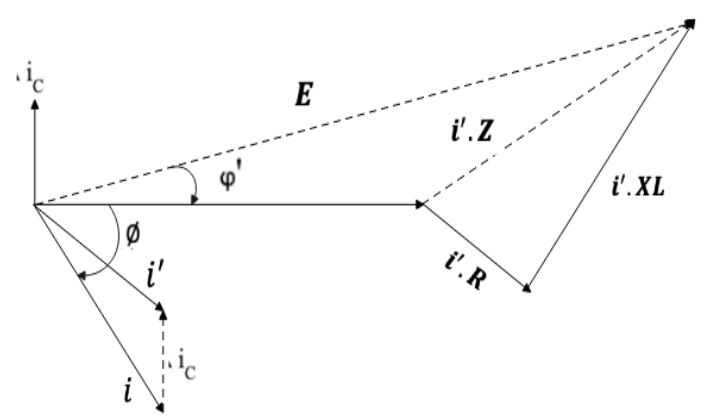

(b)

Figure 6. (a) Single-line Diagram of a Shunt RPC Transmission Line, (b) Single Line Diagram of a Shunt Compensated Phasor diagram.

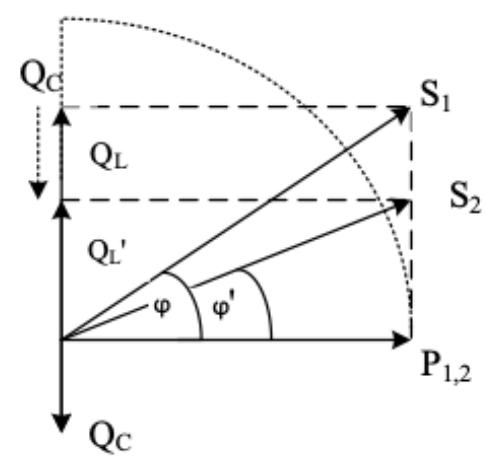

Figure 7. RPC Process Power's diagram 
The terms specified in Figure 7 are calculated with the following equations' help.

$S_{1}=\sqrt{\left(P_{1}^{2}+Q_{L}^{2}\right)}$

$S_{2}=\sqrt{\left(P_{2}^{2}+Q_{L^{\prime}}^{2}\right)}$

$P_{1}=\sqrt{3}$.u.i.cos $\cos$ ?

$P_{2}=\sqrt{3} \cdot u \cdot i^{\prime} \cdot \cos \cos \varphi^{\prime}$

$Q_{C}=P_{1,2} \cdot\left(\operatorname{tg} \varphi-\operatorname{tg} \varphi^{\prime}\right)$

$Q_{t}=i^{2} \cdot R \cdot t$

$i=\frac{\sqrt{P_{1}^{2}+Q_{L}^{2}}}{V_{1}}$

$i^{\prime}=\frac{\sqrt{P_{2}^{2}+Q_{L^{\prime}}^{2}}}{V_{2}}$

$c c c=\frac{i-i \prime}{i^{\prime}}$
$P_{1}, P_{2}$; active power without and with RPC, $\Delta Q_{c} ; \mathrm{RPC}$ capacitor value (supplied by capacitors), $Q_{L}, Q_{L}$ '; reactive power without and with RPC, $\mathrm{S}_{1}, \mathrm{~S}_{2}$; apparent power without and with RPC, $i, i^{\prime}$; line current without and with RPC, $Q_{T}$; thermal energy, ccc; system current carrying capacity [22], $\varphi, \varphi^{\prime}$; phase angle without and with RPC.

\subsection{Reactive power compensation system design and modelling}

\subsubsection{MATLAB-Simulink Processes of the System}

Subsystem designs obtained in previous networks combined in this network and Simulink modelling of the system as a whole was obtained (Fig.8).

Designed electrical circuits and performance data obtained before and after the RPC due to the simulation were the basis for the experimental setup (Fig. 9).

The meanings of the terms mentioned in the above equations are explained below.

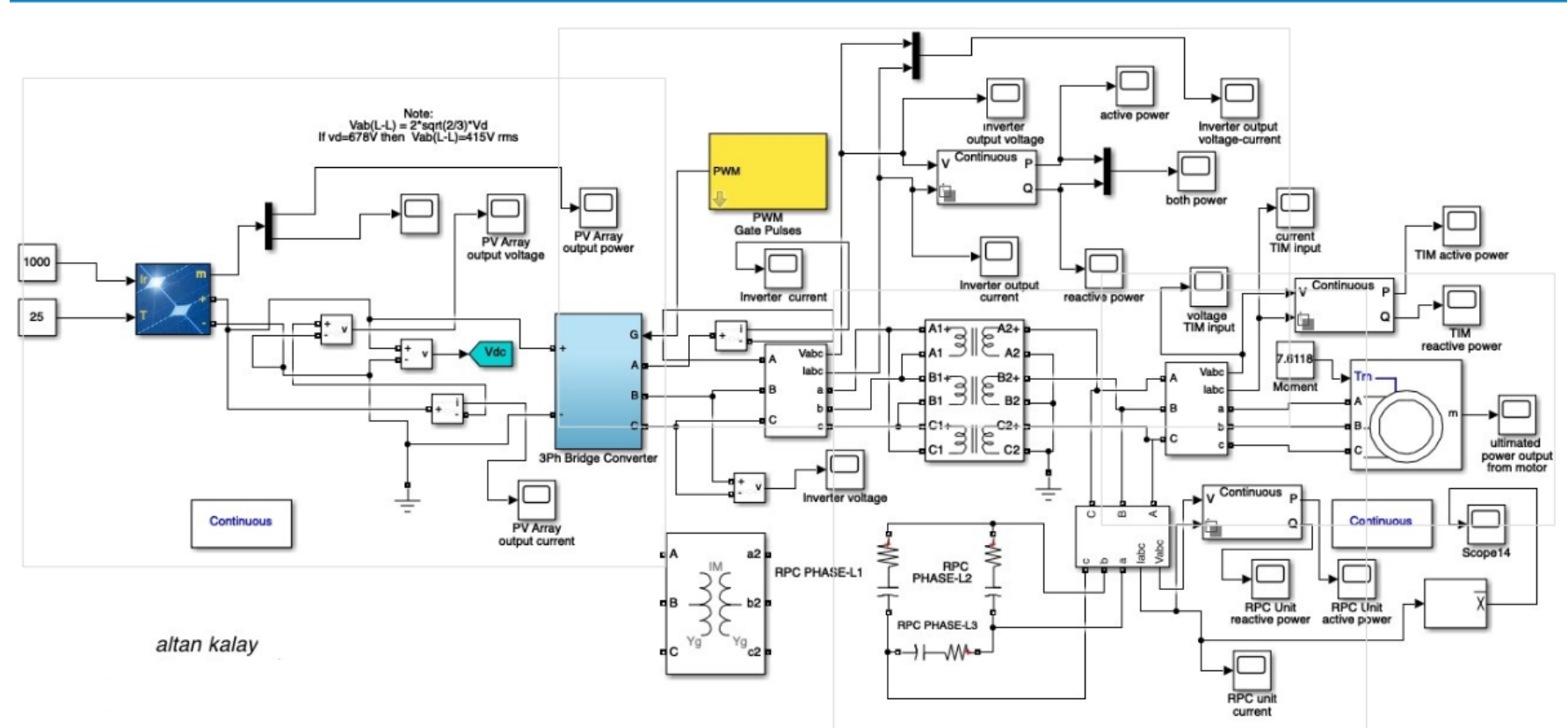

Figure 8. Simulink Modelling of General System. 


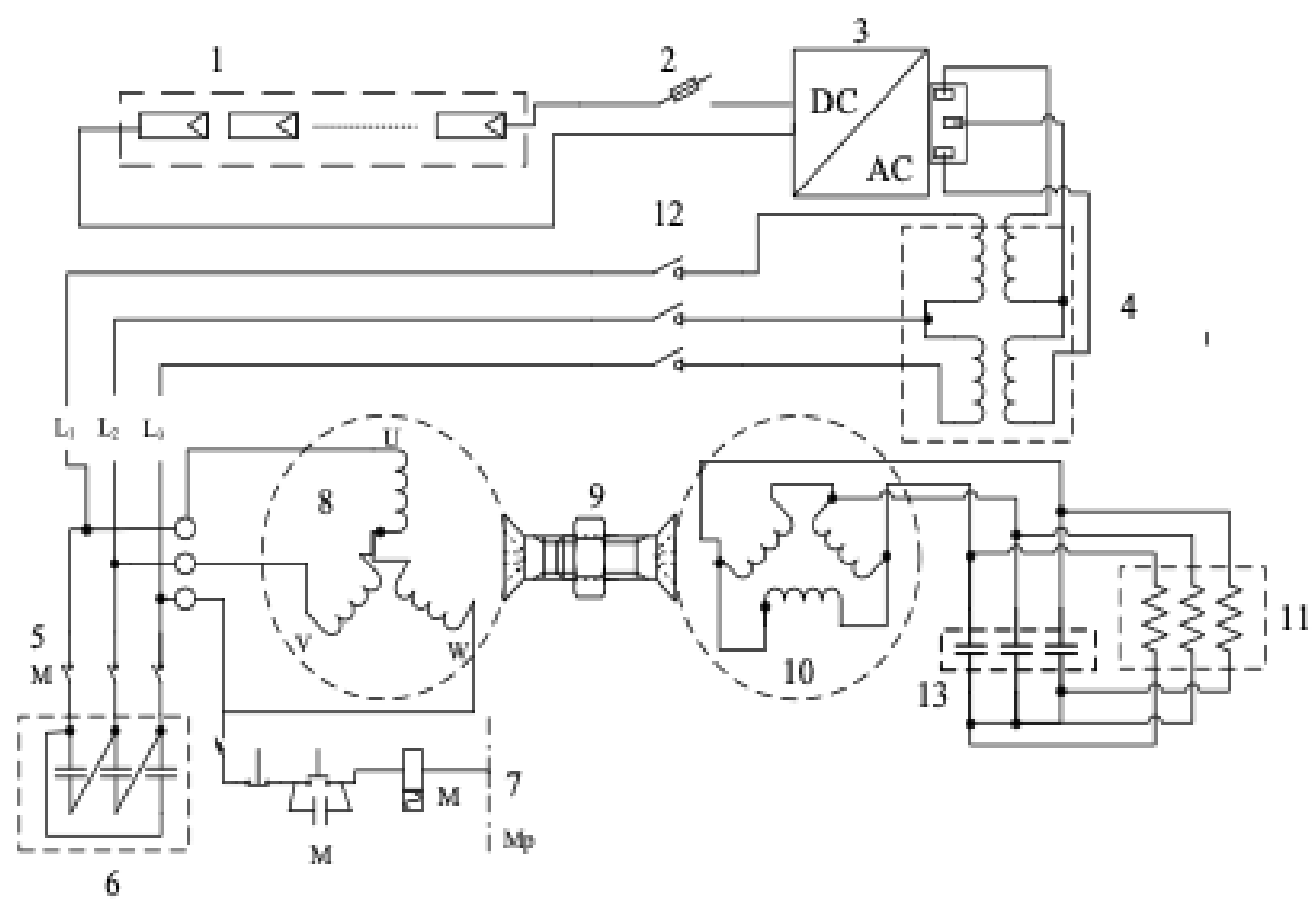

Figure 9. Electric Circuits of the System.

\subsection{2. $\quad$ RPC Control}

Some main approaches are currently being adopted in using techniques for RPC. These include series compensation, shunt reactor, static VAR compensation (SVC), static synchronous compensation (STATCOM), and which technological basis of this work is the shunt constant compensation technique. A possible explanation is that all capacitor banks permanently connect the system when the power factor descends the threshold value. The power analyzer used in this system can measure and monitor the power factor values instantaneously (Figure-10, step-1) when the power factor values descent the threshold value (these values should be $0,90+)$, the command-control circuit to be activated (Figure-10, step-2). The contactor's power contacts (Figure 9, no 5) turn into the closed position. Capacitor banks deliver capacitive current and power to the load after energizing (Figure-10, step-3). Contrary to reactive-inductive power taken by the load, reactivecapacitive power in the opposite direction is activated, and total reactive power reduction is performed (Figure 7). The update in parameters such as current, power, and power factor, which are determinants of system performance, obtained after RPC, are given in Table 1.

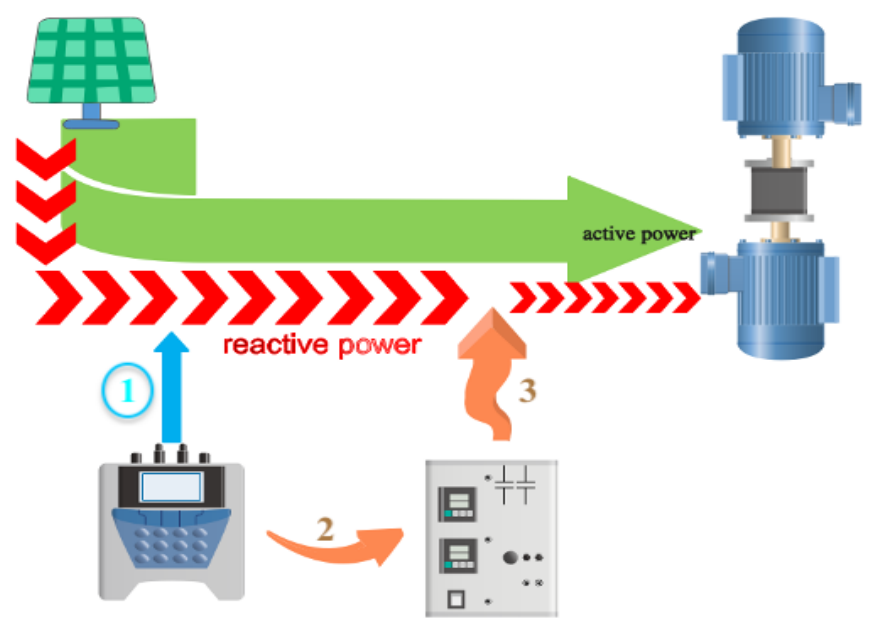

Figure 10. RPC Control Steps

Table 2 RPC Results Before/After

\begin{tabular}{ccccc}
\hline Parameter & Symbol & $\begin{array}{c}\text { Standard } \\
\text { operation }\end{array}$ & $\begin{array}{c}\text { With } \\
\text { RPC }\end{array}$ & Units \\
\hline $\begin{array}{c}\text { Reactive } \\
\text { Power }\end{array}$ & $Q$ & $1.131,03$ & 259,3092 & V.A.R \\
Power Factor & $\cos \varphi$ & 0,75 & 0,95 & -- \\
Active Power & $P$ & $1.283,04$ & $1.283,04$ & Watt \\
Apparent & $S$ & $1.710,80$ & $1.309,40$ & V.A \\
$\quad \begin{array}{l}\text { Power } \\
\text { Thermal } \\
\text { Energy }\end{array}$ & $Q_{\text {heat }}$ & 267,203 & 147 & Joule \\
$\begin{array}{c}\text { Current/phase } \\
\text { CCC }\end{array}$ & $i$ & 3,6 & 1,989 & Amper \\
& -- & 100 & 123,462 & --
\end{tabular}




\subsubsection{Experimental Setup of the System}

The experimental application phase was started after completing the mathematical calculation and simulation processes. The electrical circuit was created by bringing the system components together (Fig. 11).

During the experimental setup, the data obtained from the power analyzer are imported to EXCEL via power analyzer database interface, then transferred to the MATLAB environment via the program's import data function. The graphic curves were obtained after the necessary code software was realized [23].

After that, the curve outputs of the current values from the inverter output obtained to obtain the system's total current carrying capacity. In addition to the data obtained, the concrete expression of the total current carrying capacity increase in the system has been reached with MATLAB encodings.

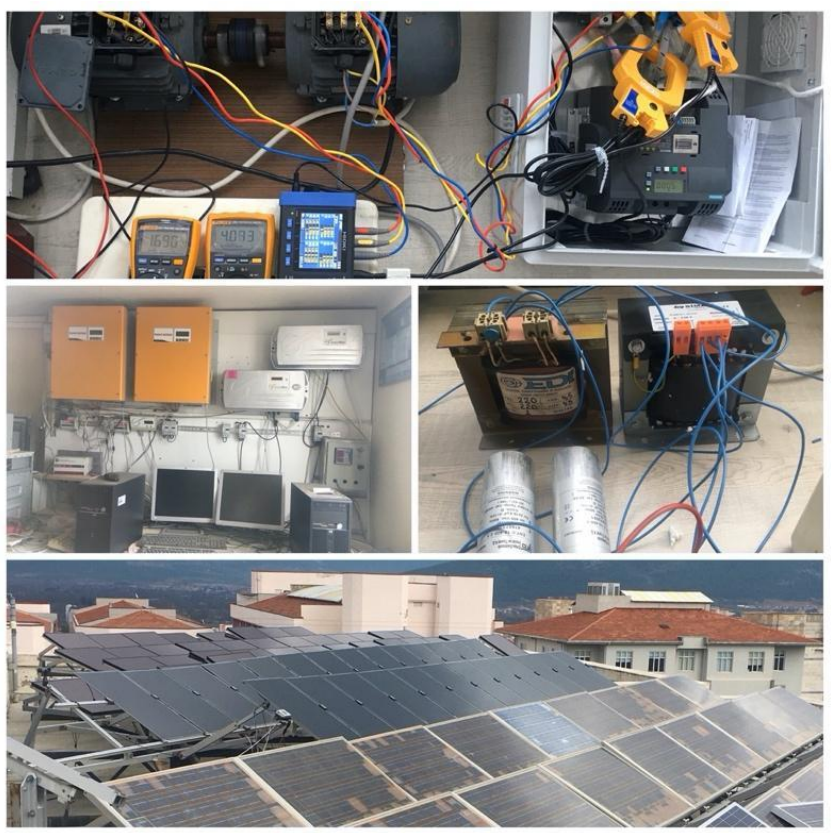

Figure 11. Experimental Setup.

\section{Result}

\subsection{PV Array Performance Results}

The most important of these parameters; is a unique time point in the I-V curves and P-V curves, called; maximum power point (MPP), where the entire PV system operates at maximum efficiency and generates maximum output power. Because it is essential to understand how PV array structure and topology correspond to MATLAB-Simulink [24]. It's necessary to investigate some basic variations such as I-V curves and $\mathrm{P}-\mathrm{V}$ curves

At this network of the study, as a result of the data obtained, Simulink modelling of PV array was performed. These required parameter values were calculated, and these results were combined with experimental setup results. The module topology primarily follows PV system I-V curves with the module tag data (Figure 12).

The reason for differences between the mathematical result, simulation, and experiment is that thermal losses of wiring, circuit breakers, and other experimental setup components are ignored in simulation and calculation.

On the other hand, PV module manufacturing values such as $V_{O C}-I_{M P P}$, different from experimental setup values. At first, in simulation and calculation, the fabric values are used.
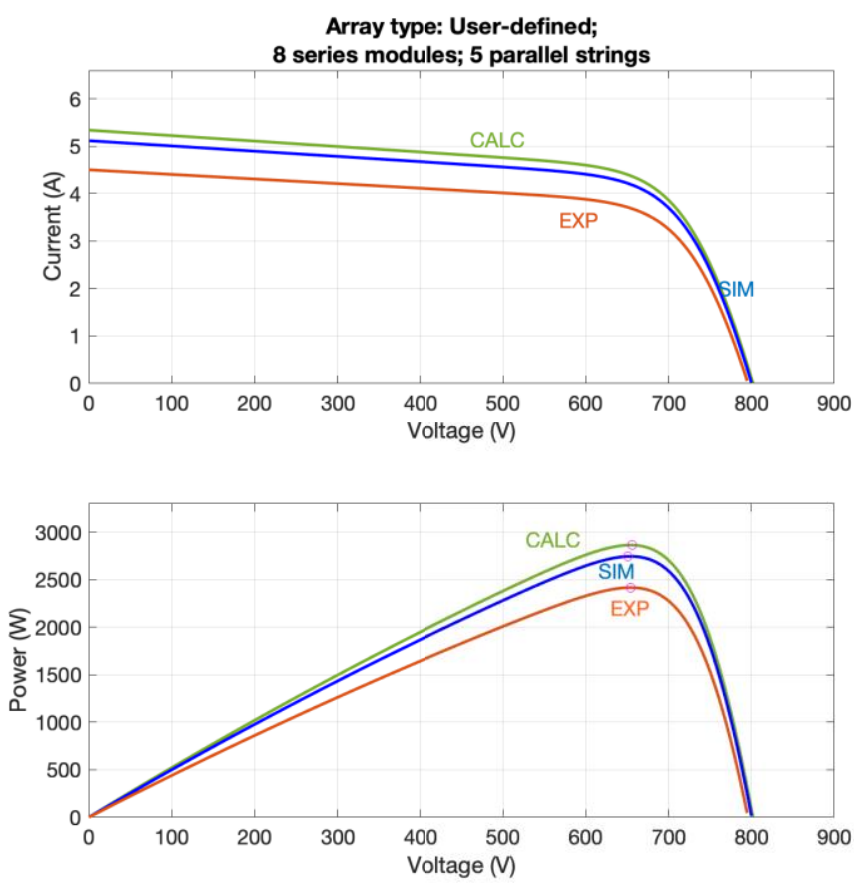

Figure 12. PV Array System Performance Curves.

\subsection{Thermal Energy Change Function Curves}

According to mathematical, simulation, and experimental setup results, thermal energy values that occur in response to each current value received during the measurement period; while around 250 Joule before optimization, after RPC application; decreased to about 150 Joule (Fig.13).

\subsection{Thermal Energy Change Function Curves}

According to mathematical, simulation, and experimental setup results, thermal energy values that occur in response to each current value received during the measurement period; while around 250 Joule before optimization, after RPC application; decreased to about 150 Joule (Fig.13).

\subsection{Thermal Energy Change Function Curves}

According to mathematical, simulation, and experimental setup results, thermal energy values that occur in response to each current value received during 
the measurement period; while around 250 Joule before optimization, after RPC application; decreased to about 150 Joule (Fig.13).

\subsection{Thermal Energy Change Function Curves}

According to mathematical, simulation, and experimental setup results, thermal energy values that occur in response to each current value received during the measurement period; while around 250 Joule before optimization, after RPC application; decreased to about 150 Joule (Fig.13).

\subsection{Current-Active Power Function Curves}

'Current-Active Power Relationship' curves, which is one of the study's critical performance output combinations; it's obtained as a result of software coding performed with data obtained from experimental setup, simulation, and mathematical calculation environments. The load line current, which was around 3,5 Amperes in standard operating conditions, decreased to approximately 2,5 Amperes after RPC. According to these curves, when the processes before and after RPC application are evaluated; higher current values have obtained lower values and have produced the same active power values after RPC processes (Fig. 14).

\subsection{Current Carrying Capacity}

One of the essential indicators in optimizing the system is the change of current carrying capacity over time. The values obtained during the experimental setup, calculation, and working simulation phases. Which were carried out to get this performance output, had high values at the beginning of the working period, due to the moment of starting. Still, it gained a stable character towards the end of the measurement period. With optimization, an increase of approximately 24\% was achieved in the system's current-carrying capacity (CCC) (Fig.15).
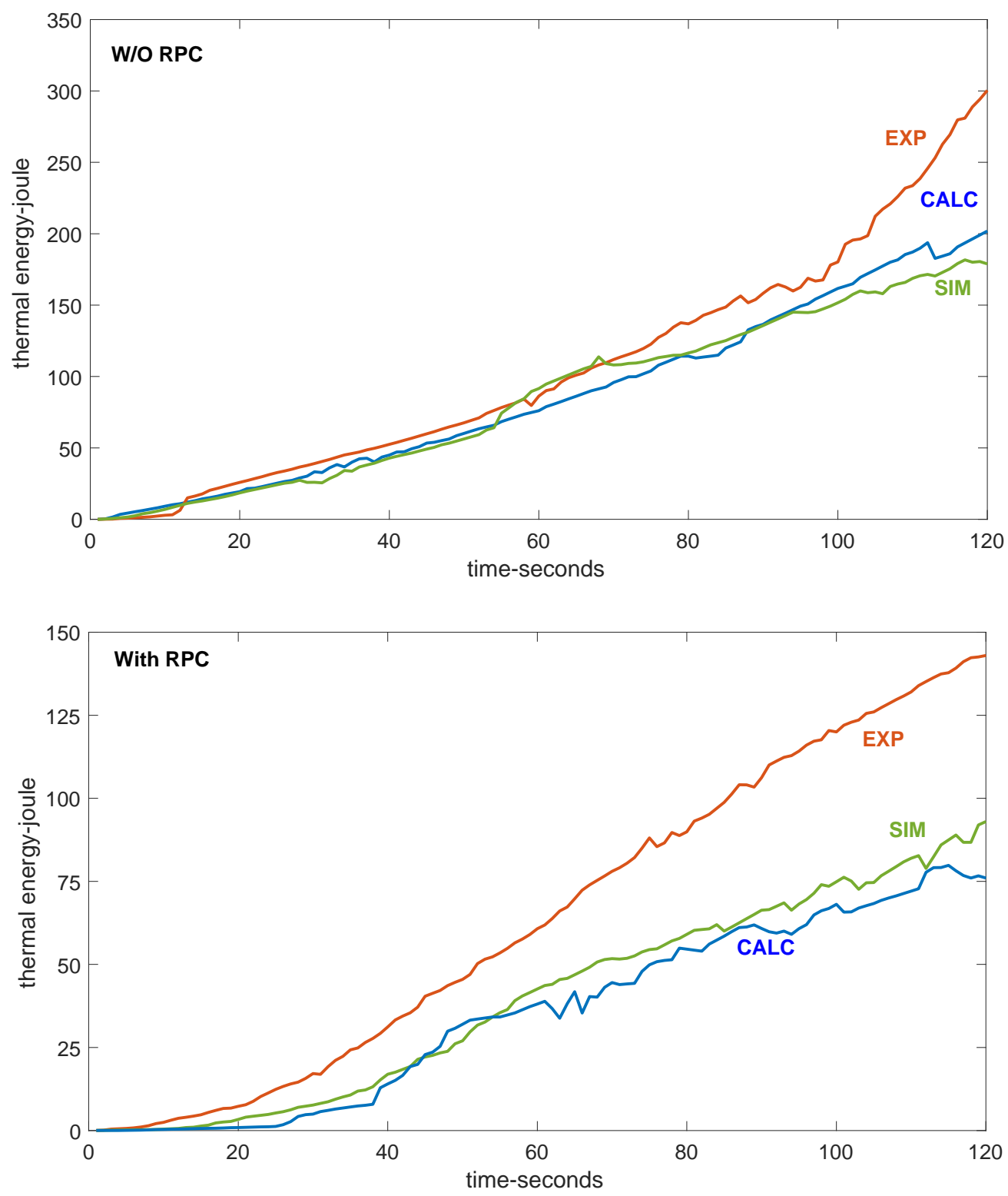
Figure 13. Thermal Energy-Time Characteristic Curves.
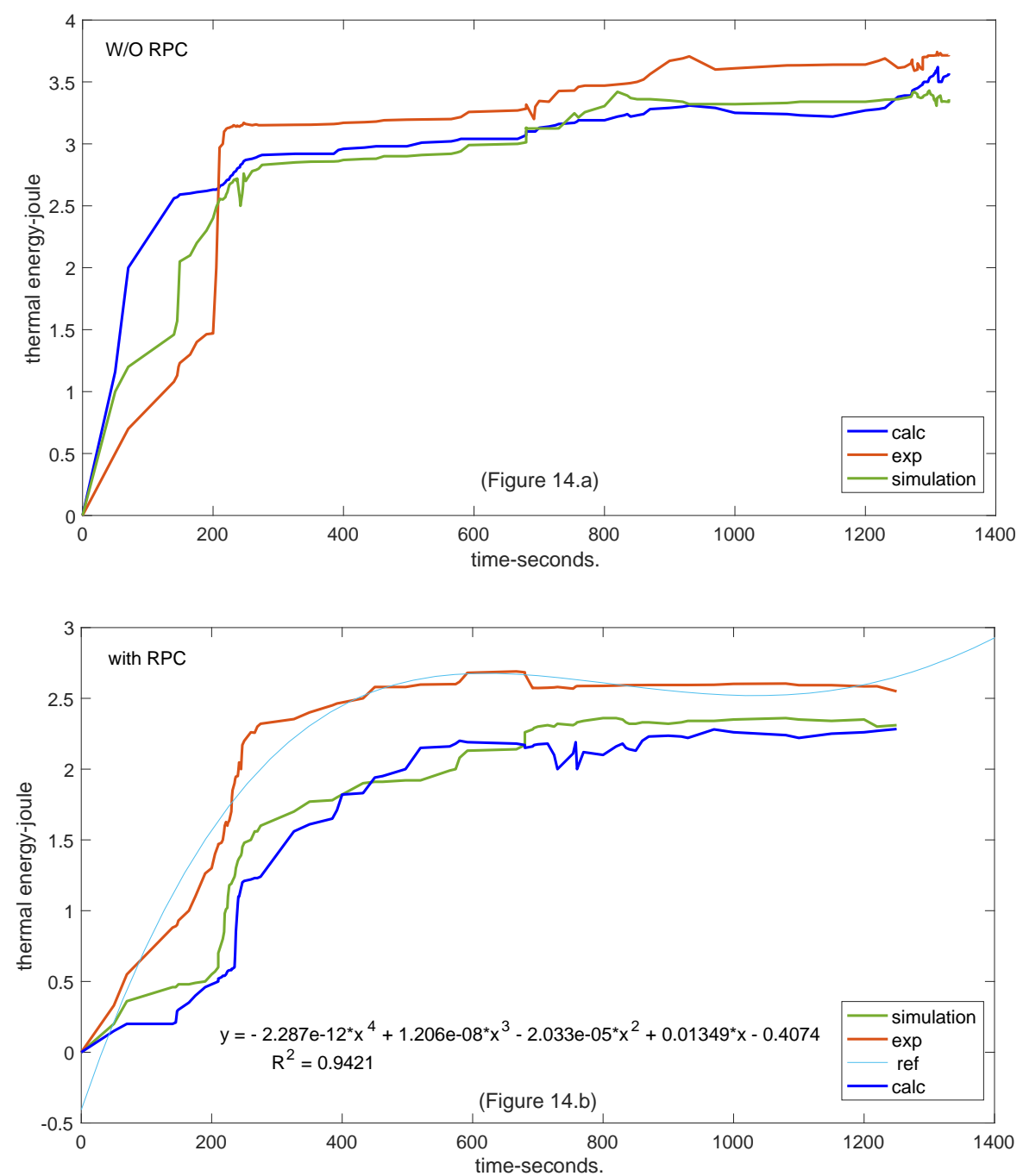

Figure 14. Current-Active Power Relationship Curves without RPC (a) -with RPC (b).

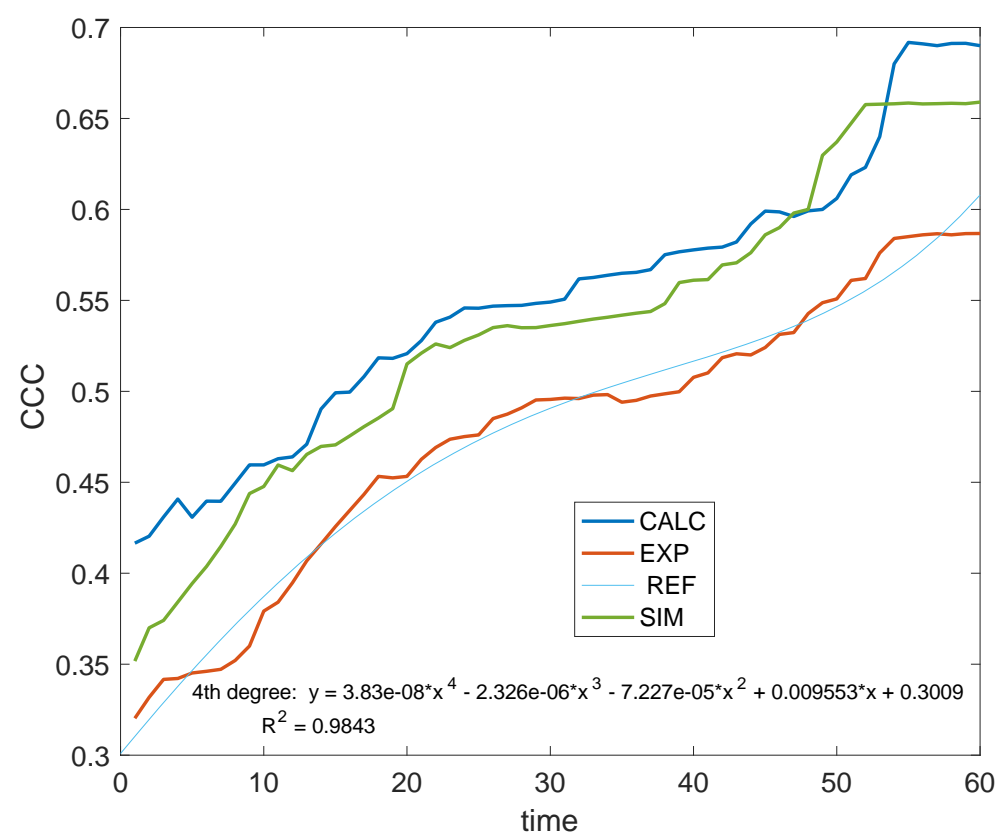


Figure 15. Current Carrying Capacity Curves.

The best representation of the thermal energy-time characteristic curve given in Fig. 13 is, as shown in equation 15.

$f(x)=-0,0001083 x^{3}+0,02218 x^{2}+0,08807 x-1,069$

$R^{2}=0,9993$

The best representation of the current-active power relationship function curve shown in Fig. 14 is given in equation 16.

$$
\begin{gathered}
f(x)=-2.287 e-12 x^{4}+1.206 e-08 x^{3}-2.033 e-05 x^{2} \\
+0.01349 x-0.4074
\end{gathered}
$$

$R^{2}=0.9421$

The best representation of the current-carrying capacity curve shown in Fig. 15 is given in equation 17.

$$
\begin{gathered}
f(x)=3.83 e-08 x^{4}-2.326 e-06 x^{3}-7.227 e-05 x^{2} \\
+0.009553 x+0.3009
\end{gathered}
$$

$R^{2}=0.9843$

\section{Conclusion}

In this study, PV system transmission optimization is accomplished by way of RPC. During this process, some parameters such as current, active power, current carrying capacity (CCC), thermal energy, and time are controlled and updated. As a result of the decrease in current values without a reduction of active power (Fig.14), CCC of the system is increased (Fig.15), due to the reduction in current; a decrease in thermal energy was obtained (Fig.13).

The decrease in thermal energy increases the system's efficiency and in the final analysis; led to performance development obtained with the RPC process performed in the power transmission part of the PV system has provided an efficiency increase all over the system. Thus, it gained; minimal cost, maximum profit.

'Curve Fitting Application' was applied to the curves obtained from the MATLAB. Each experimental setup curve's mathematical function was obtained to support performance improvement's definition (Fig. 16). The primary purpose of using the $\mathrm{CF}$ applications was supporting as secondary data for acquiring modelling. Simultaneously, these data provide an additional contribution in reinforcement the findings.

It is hoped that the data and modelling obtained in this study will serve as a scientific helpfully base for research, especially in PV pumping system, e.g., in the future.

On the other hand, inside this system, some switching problems about capacitor current should be developed, and RPC's control technique could be updated faster. Although the regulating elements in the system such as voltage transformer bring additional cost, it will reduce the energy consumption cost during the amortization period.

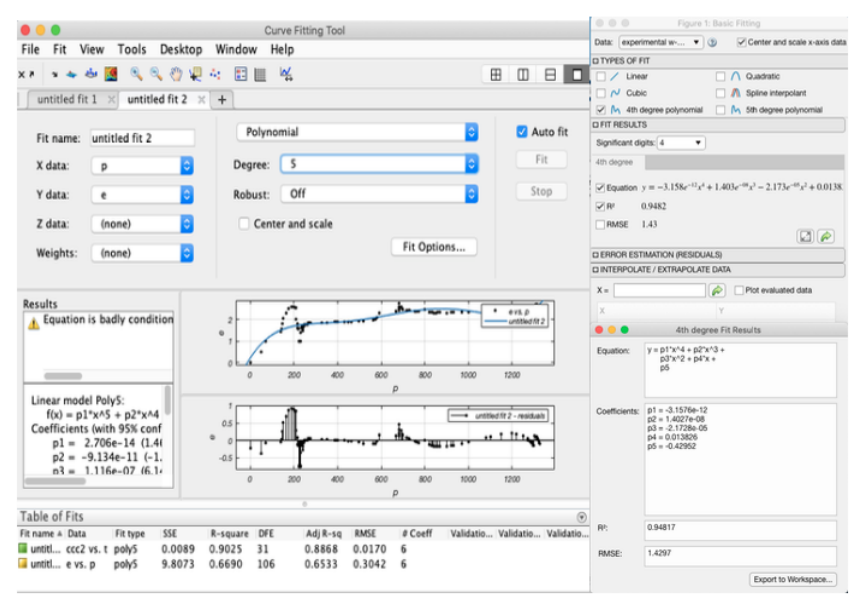

Figure 16. CF Results of Functions and R-squared coefficients

\section{Acknowledgement}

The authors would like to thank Assoc. Prof. Dr Rüştü Eke for the use of the photovoltaic system established on the roof of the library of Muğla Sitkı Koçman University.

\section{References}

[1] Vidyanandan, K.V., "An Overview of Factors Affecting the Performance of Solar PV Systems", Energy Scan, A house journal of Corporate Planning, NTPC Ltd., issue 27, Feb.2017, pp.2-8.

[2] Huang B-J., Huang Y-C., Chen G-Y., Hsu P-C., Li K., 'Improving PV Solar System Efficiency Using OneAxis 3 Position Sun Tracking", PV Asia Conference, Energy Procedia 33, 2012, p. 281.

[3] Serhan M. and El-Chaar L., 'Two Axes Sun Tracking System: Comparison with a Fixed System.", International Conference on Renewable Energy and Power Quality (ICREPQ'10), 2010.

[4] Heidari M., 'Improving Efficiency of PV System by Using Neural Network MPPT and Predictive Control of Converter", International Journal of Renewable Energy Research, Vol 6, No 4, 2016.

[5] Abdolzadeh M., Ameri M., 'Improving the Effectiveness of a PV Water Pumping System by Spraying Water over the Front of PV Cells", Renewable Energy, Vol. 34, 2009, pp.91-96.

[6] Boztepe M., Factors affecting efficiency in PV, EMO IV. Energy Efficiency Days in, emo.org.tr, 2017.

[7] Terki, A. Moussi, A. Betka A., Terki N., "An improved efficiency of fuzzy logic control of PMBLDC for PV pumping system", Applied Mathematical Modelling Vol. 36, 2012, pp.934-944. 
[8] Wong L.K., Leung F.H.F., Tam P.K.S., "Stability analysis of fuzzy logic control systems", Electronic Letters Vol.36(12), 2000, pp.1085-1086.

[9] Akbaba, M., "Dynamic Performance of a photovoltaic boost converter powered DC Motorspump system", In; Proceeding of IEEE International Conference, IEMDC'99, 1999, pp.1-6.

[10] Appelbaum, J., "Starting and Steady-State Characteristics of DC Motor Powered by Solar Cell Generator", IEEE Trans Energy Conv No. 1 (1986), pp.17-25.

[11] Appelbaum, J., Sarme, M.S., "The Operation of Permanent Magnet DC Motor Powered by Common Source of Solar Cells", IEEE Trans Energy Conv No. 4 (1989), pp.635-642.

[12] Makhlouf M., Messai F., Benalla H., "Vectorial Command of Induction Motor Pumping System Supplied by a Photovoltaic Generator", Journal of Electrical Engineering, Vol. 62, No.1, 2011, pp.3-10.

[13] BAHT, SR et al., "Performance Optimisation of Induction Motor-Pump using Photovoltaic Energy Source", IEEE Trans Ind App 23 No. 6 (1987), pp.995-1000.

[14] Siddalinga. S. Nuchhi, Raghavendra. B. Sali, Dr. Shekhappa G. Ankaliki, "Effect of Reactive Power Compensation on Voltage Profile", International Journal of Engineering Research \& Technology (IJERT)ISSN: 2278-0181www.ijert.org Vol. 2 Issue 6, 2013.

[15] Ganiyu A. A., Olawale 0. O., "Research Article; Effect of Reactive Power Flow on Transmission Efficiency and Power Factor", International Journal of Recent Scientific Research, Vol.6, Issue 7, 2015, pp.52495253,

[16] Choi J.Y, Rim S., Park J., "Optimal real-time pricing of real and reactive powers", IEEE Transactions on power systems, Vol.13, No 4, 1998, pp.1226-1231.
[17] Kahn E., Baldick R., "Reactive power is a cheap constraint", The Energy Journal, Vol.15, No 4, 1994, pp.191- 201.

[18] Marsteller G.F., "Analytical notes on the economics of power factor correction, Journal of the Institution of Electrical Engineers, Vol.6, No.6, pp.975-983, 2008.

[19] Ikegami T., Maezono T., Nakanishi F., Yamagata Y., "Estimation of equivalent circuit parameters of PV module and its application to optimal operation of PV system", Solar Energy Materials \& Solar Cells 67, 2001, pp.389-395.

[20] Wengerkievs C.A.C., Elias R.d. A., Batistela N.J., Sadowski N., Kuo-Peng P., Lima S.C., Pedro A. D Silva, Beltrame AY, "Estimation of Three-Phase Induction Motor Equivalent Circuit Parameters from Manufacturer Catalog Data", Journal of Microwaves, Optoelectronics and Electromagnetic Applications, Vol. 16, No. 1, March 2017.

[21] Lionginas L., "Compensation of Reactive Power of AC Catenary System", 10th International Scientific Conference Transbaltica 2017: Transportation Science and Technology, Procedia Engineering 187, 2017, pp.185-197.

[22] Darwish E.M., Hasanien H.M., Atallah A., El-Debeiky S., "Reactive power control of three-phase low voltage system based on voltage to increase PV penetration levels", Ain Shams Engineering Journal, Vol.9, Issue 4, 2018, pp.1831-1837.

[23] https://uk.mathworks.com/help/matlab/standard -file-formats.html (access date: 13.02.2010)

[24] Fara L., Craciunescu D., "Output Analysis of StandAlone PV Systems: Modelling, Simulation, and Control", Sustainable Solutions for Energy and Environment, EENVIRO, Energy Procedia-112, 2017, pp.595-605. 